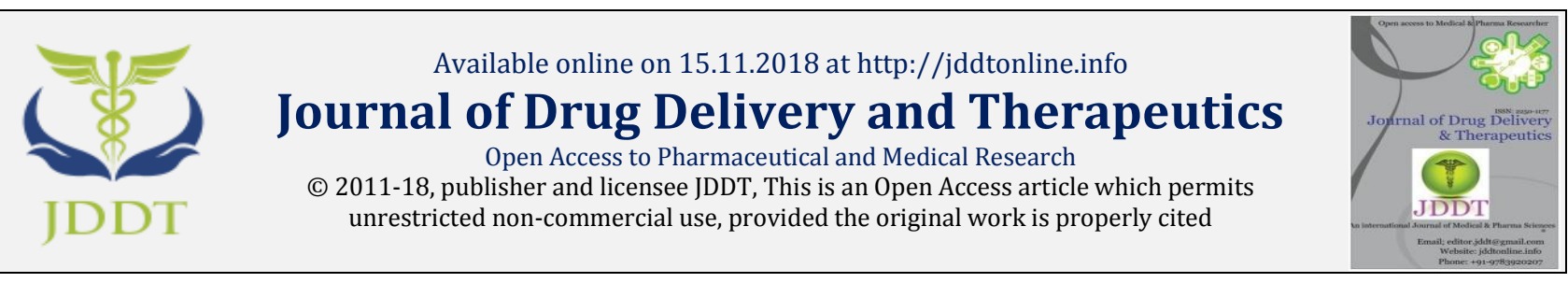

Open $\odot$ Access

Research Article

\title{
Assessment of Fatty Acid, Proximate and Quantitative Phytochemical Compositions of Matured Stem of Costus afer (Bush Cane).
}

\author{
Nwauche K.T., ${ }^{*}$ Anacletus F.C. ${ }^{2}$ and Ighorodje-Monago C.C. ${ }^{2}$ \\ ${ }^{1}$ Department of Chemical Sciences (Biochemistry Unit), Rhema University, Aba, Abia State, Nigeria. \\ ${ }^{2}$ Department of Biochemistry, Faculty of Science, University of Port Harcourt, Choba, Rivers State, Nigeria.
}

\begin{abstract}
This study estimated the fatty acid, proximate and quantitative phytochemical compositions of Costus afer matured stem collected from Choba campus of University of Port Harcourt, in Choba community, Rivers State. This was carried out using standard procedures of analysis (fatty acid and proximate) as well as gas chromatographic method (quantitative phytochemical analysis). The fatty acid analysis of the plant stem revealed high contents of linolenic acid (32.26\%), linoleic acid $(25.89 \%)$ and palmitic acid $(25.48 \%)$ and moderate levels of oleic acid (7.11\%) and stearic acid (6.36\%) while myristic acid, palmitoleic acid, arachidonic acid, behenic acid and lignoceric acid was low and caprylic acid, capric acid, lauric acid, margaric acid, arachidonic acid, erucic acid were absent. The results of the proximate composition of the stem of Costus afer indicated that total carbohydrate composition of Costus afer stem was the highest (54.98\%) while crude fat had the lowest value of $1.15 \%$. The moisture content had a moderate value of $22.15 \%$ while total ash $(4.60 \%)$, crude protein $(7.72 \%)$ and crude fibre $(9.40 \%)$ values were low. The gas chromatographic analysis of the stem indicated that the total alkaloid composition was $70.59 \mathrm{mg} / 100 \mathrm{~g}$ with high compositions of papaverine (44.72\%), methyl morphine $(23.24 \%)$, morphine $(17.92 \%)$ and narcotine $(14.11 \%)$. The total flavonoids concentration was $28.29 \mathrm{mg} / 100 \mathrm{~g}$. Myricetin $(69.79 \%)$ had the highest value with moderate levels of quercetin $(14.88 \%)$ and kaempferol $(9.78 \%)$. The total composition of saponin was $2.87 \mathrm{mg} / 100 \mathrm{~g}$. The sapogenin content of the stem $(39.20 \%)$ was the highest with moderate levels of diosgenin $(26.13 \%)$, saponine $(22.12 \%)$ and tigonine $(9.76 \%)$ while gitogenin value $(2.28 \%)$ was observed to be low. The analysis of the plant stem showed the presence of glycosides $(22.35 \mathrm{mg} / 100 \mathrm{mg})$ made up mainly of costugenin (65.60\%), digitoxin (18.73\%), digoxin $(6.28 \%)$, salicin $(4.76 \%)$ and low levels of ouabain $(1.95 \%)$ and kaemferol-3-rhamnoside $(1.08 \%)$. The study has shown that matured stems of Costus afer can contribute greatly towards meeting human nutritional requirements and suggest the possibility of its use in folklore medicine.
\end{abstract}

Keywords: Costus afer, phytochemicals, proximate composition, fatty acids.

Article Info: Received 03 Oct, 2018; Review Completed 06 Nov 2018; Accepted 13 Nov 2018; Available online 15 Nov 2018

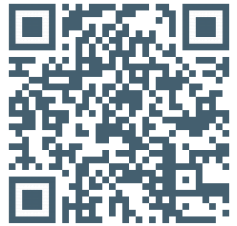

Cite this article as:

Nwauche KT, Anacletus FC, Ighorodje-Monago CC, Assessment of Fatty Acid, Proximate and Quantitative Phytochemical Compositions of Matured Stem of Costus afer (Bush Cane)., Journal of Drug Delivery and Therapeutics. 2018; 8(6):217-224 DOI: http://dx.doi.org/10.22270/jddt.v8i6.2057

Nwauche K. T., Department of Chemical Sciences (Biochemistry Unit), Rhema University, Aba, Abia State, Nigeria.

\section{INTRODUCTION}

Plants are important sources of foods and natural drugs. Nature has been a source of medicinal agents for thousands of years and an impressive number of modern drugs have been isolated from natural sources, mainly based on their use in traditional medicines or phytomedicines. In Nigeria many indigenous plants are used as spices, food or medicine. These plants often exhibit a wide range of biological and pharmacological activities. Extracts from the roots, barks, seeds and fruits of these plants are used in the preparation of syrups in traditional medicine as cough suppressant and in the treatment of oxidative related diseases.[1] It is generally assumed that the active constituents contributing to these protective effects are the phytochemical constituents, vitamins and minerals.[1] Phytochemical constituents exhibit a wide range of biological effects resulting in their protective or disease preventive properties. These are some possible actions: antioxidant, hormonal action, stimulation of enzymes and interference with DNA replication, anti-microbial effect, and physical action. [2] [3] [4] Medicinal plants play a great role in human life and have substances that are used for traditional therapeutic and modern drug production purposes in primary health care delivery. These medicinal plants might contain one or more compounds having medicinal activity. These compounds could be used or 
mixed together to make effective medicines.[5] Medicinal plants have long been a subject of curiosity and need. Herbal medicines are usually in the form of vegetable drugs or their extracts that are utilized by man for the treatment of disease or to maintain a state of improved health. With the increasing interest in medicinal plants, arises the need to investigate the biochemical basis of the action of plants and their extracts. This further emphasizes the need to link phytochemistry and pharmacology. In addition, some of these medicinal plants have been found to be rich in nutrients, thus necessitating the investigation of their nutrient composition and potential as sources of nutrients or as food. Therefore the knowledge of the chemical composition of foods is the first essential in dietary treatment of disease or in any quantitative study of human nutrition.[6] Indigenous people of Africa employ at least 20,000 plant species for medicines and related purposes.[7] In addition to medicinal properties many of the plants are high in protein, vitamins, mineral and carbohydrate for both human and livestock.

The plant Costus afer is among 150 species of stout, perennial and rhizomatous herbs of the genus $\operatorname{Costus}^{[8]}$.

Costus afer is found in the forest belt from Senegal east to Ethiopia and south to Tanzania, Malawi and Angola. It is often planted in home gardens for medicinal purposes. Costus afer belongs to the family Costaceae a monocot and a relatively tall, herbaceous, unbranched tropical plant with creeping rhizome. It is commonly found in moist or shady and river banks forest of West and Tropical African countries including Senegal, South Africa, Guinea, Nigeria, Ghana and Cameroon.[8] [9] Costus afer is pantropical and comprises of about 70 species, which about 40 species are found in tropical America, about 25 in tropical Africa and about 5 in South-East Asia.[10] Costus afer is commonly called bush cane. [11] [12] It is known as "Okpete" or "Okpoo" in Igboland, "Kakizuwa" in Hausa, "tete-egun" in Yoruba and "Mbritem" in Efik, all in Nigeria. Anglophone Cameroon calls it "Monkey sugar cane." [12] [13]

Costus afer is perennial, rhizomatous herb that can attain a height up to $4 \mathrm{~m}$. Leaves are arranged spirally, simple and entire. Sheath is tubular, closed, and green with purple blotches; ligule $4-8 \mathrm{~mm}$ long; blade is elliptical to obovate, $15-35 \mathrm{~cm} \times 3.5-9.5 \mathrm{~cm}$, base is rounded to subcordate, apex is acuminate, and margin is sparsely hairy, usually glabrous above and sometimes shortly hairy beneath. Inflorescence is a very compact, terminal, conical spike $2.5 \mathrm{~cm}-7.5 \mathrm{~cm}$ long, sessile; bracts is oblong, convex, $3.5 \mathrm{~cm}$ long, densely inbricate, upper ones often smaller, apex is truncated to rounded, green with purple markings, each subtending 2 flowers; bracteoles is boat shaped, $2.5 \mathrm{~cm} \mathrm{x}$ $1 \mathrm{~cm}$, keel is thick and ridged, pale green with pink markings and thin papery margin. Flowers are bisexual and zygomorphic. [10]

\section{MATERIALS AND METHODS}

\section{Collection and Identification of Plant Samples}

Fresh stems of Costus afer were obtained from Choba campus of University of Port Harcourt, in Choba community. They were authenticated by a Plant taxonomist at the Department of Plant Science and Biotechnology, Faculty of Science, University of Port Harcourt, Nigeria where a voucher specimen was also deposited. The stems were washed, cut into pieces and sun dried. They were later ground into fine powder with the aid of a clean dry electric grinder ((Sorex SHB-520, Korea)) and stored in an air tight container.

\section{Determination of Proximate Composition}

Proximate analysis to determine the moisture, crude protein, fat, ash, fiber and total carbohydrate contents of the samples were carried out according to the standard methods. [14]

\section{Determination of Moisture Content}

\section{Procedure}

An empty silica dish was allowed to cool in the desiccator, after which its weight was taken. Then $1.0 \mathrm{~g}$ of the sample was weighed into the silica dish and placed in the oven at about $105^{\circ} \mathrm{C}$ for 24 hours. It was cooled in desiccator to the room temperature. The silica dish and contents was weighed and later placed back in the oven for another 24 hours to ensure complete drying. The cooling process in the desiccator was repeated until a constant weight was obtained. The calculation is shown in appendix C.

\section{Determination of Ash Content}

\section{Procedure}

To a pre-weighed, clean, empty petri-dish, $1.0 \mathrm{~g}$ of the sample was added and placed in the muffle furnace at $550^{\circ} \mathrm{C}$ for 4 hours. The sample was allowed to cool in the desiccator. This was repeated until a constant weight was obtained. The weight of the petri-dish and residue was taken. The calculation is shown in appendix C.

\section{Determination of the Protein Content}

\section{Procedure}

\section{Digestion}

To $1.0 \mathrm{~g}$ of the sample in a $100 \mathrm{ml}$ Kjeldahl digestion flask, was added $3 \mathrm{~g}$ of Kjeldahl digestion catalyst, $20 \mathrm{ml}$ of the $1.25 \%$ concentrated sulphuric acid and a few anti-bumping agents. The flask was fitted to a reflux condenser and gently heated until foaming had ceased, and the contents became completely liquefied. Then the content of the flask was heated intensely, with occasional rotation of the flask, until the colour of the digest changed from ash to bluegreen or pale green colour. The flask was allowed to cool and its contents were quantitatively transferred into a $100 \mathrm{ml}$ volumetric flask and made up to the $100 \mathrm{ml}$ mark with distilled water.

\section{Distillation}

Twenty $\mathrm{ml}$ of this diluted digest was transferred into a $150 \mathrm{ml}$ distillation flask. The flask into which some antibumping chips have been added was connected to a condenser whose receiver was attached to a Buchner funnel immersed in a $400 \mathrm{ml}$ beaker containing $10 \mathrm{ml}$ of $2 \%$ boric acid solution masked with 2 drops of double (methyl red-methylene blue) indicator. Then, $20 \mathrm{ml}$ of $40 \% \mathrm{NaOH}$ solution was added to the flask using a syringe. Distillation was stopped when the volume in the beaker was about the same in the original volume, and the colour of the boric acid in the receiver flask changed from purple to pale green. The ammonia was liberated into the boric acid solution. The distillation unit was dismantled and rinsed with distilled water.

\section{Titration}

The distillate (boric acid-ammonia solution) was titrated with $0.1 \mathrm{M}$ hydrochloric acid, until the colour changed to pink, which marked the end of titration. The titre value was recorded and this was used to determine the nitrogen content from which the protein value was calculated by 
multiplying with the Nitrogen factor, 6.25 . The calculation is shown in appendix $\mathrm{C}$.

\section{Determination of the Crude fat content}

\section{Procedure}

Extracting flasks $(250 \mathrm{ml})$ capacity was dried in the oven at $105^{\circ} \mathrm{C}$, transferred to the desiccator to cool to the laboratory temperature and their weights were measured. Petroleum ether $(250 \mathrm{ml})$ was measured into the dried flasks while $0.25 \mathrm{~g}$ of the sample was weighed into labelled porous thimbles and placed in the condenser of the soxhlet extractor, and the sample was extracted for 4 hours. The thimbles were removed with care and the petroleum ether in the top container (tube) was collected for reuse. The extraction flask was removed from the heating mantle arrangement when it was almost free of petroleum ether. The extraction flask with the oil was oven dried at $105^{\circ} \mathrm{C}$ for the period of 1 hour. The flask containing the dried oil was cooled in the desiccator and the weight of the cooled flask with the dried oil was measured.

\section{Determination of Fiber Content}

\section{Procedure}

Two grams of the pulverized sample was weighed into 1 litre conical flask and $200 \mathrm{ml}$ of $1.25 \%$ sulphuric acid was added and allowed to boil gently for 30minutes and contents were filtered through the Buckner funnel and rinsed well with hot deionised water. To the filtrate $200 \mathrm{ml}$ of the boiling $1.25 \%$ of sodium hydroxide was added, allowed to boil gently for 30 minutes and later filtered through the Buckner funnel. The residue was washed with hot demonized water, with $10 \%$ hydrochloric acid, and then followed by dimethyl ether and then dried in oven overnight at $110^{\circ} \mathrm{C}$. The residue was then transferred into the desiccator to cool before weighing. After weighing, it was ashed in the muffle furnace at $550^{\circ} \mathrm{C}$ for 90 minutes. After ashing, it was transferred to the desiccator to cool and then weighed. The calculation is shown in appendix C.

\section{Determination of Total Carbohydrate}

The total carbohydrate was determined by getting the percentage difference between the summations of values of crude protein, crude fat, crude fibre, ash and moisture content of the sample.

Energy value: The energy value was calculated using the Atwater factors 4, 9, and 4 for protein, fat and carbohydrate respectively.

\section{Phytochemical Analysis}

\section{Calibration, Identification and Quantification}

The linearity of the dependence of response on concentration was verified by regression analysis. Identification was based on comparison of retention times and spectral data with standards. Quantification was performed by establishing calibration curves for each compound determined, using the standards.

\section{Chromatographic Analysis}

Chromatographic analyses were carried out on an HP 6890 (Hewlett Packard, Wilmington, DE, USA), GC apparatus, fitted with a flame ionization detector (FID), and powered with HP Chemstation Rev A 09.01 (1206) software. The capillary column was an AC-5 Column $(30 \mathrm{~m} \times 0.32 \mathrm{~mm} \times$ $0.25 \mu \mathrm{m}$ film thickness).

\section{Determination of Alkaloid Composition [15]}

\section{Procedure}

Five grams of the pulverized sample was macerated in hexane of $25 \mathrm{ml}$ for about 72 hours. The extract was filtered and the residue was air dried, later treated with $10 \%$ aqueous ammonia and macerated in chloroform for 24 hours. After filtration and evaporation at reduced pressure, the resultant filtrate was treated with $7.5 \mathrm{ml}, 5 \%$ aq. $\mathrm{HCl}$. The aqueous phase was made alkaline with aqueous ammonia and extracted thrice with chloroform. The chloroform was washed with water. The extract was poured into the round bottom flask of the rotary evaporator arrangement. It was separated by driving the solvent off the extract. Then the concentrated extract was dried of water by using the anhydrous sodium sulphate before gas chromatography analysis.

\section{Determination of Flavonoid Composition [16]}

\section{Procedure}

One gram of the sample was weighed into the $250 \mathrm{ml}$ conical flask capacity with addition of distilled water and boiled for 10 minutes. The flavonoid extract was obtained by pouring $100 \mathrm{ml}$ of the boiling methanol: water (70:30) $\mathrm{v}: \mathrm{v}$ into the samples in the test tubes. The mixture was allowed to macerate for about 4 hours and then filtered with Whatman filter paper No.1. The filtrate was concentrated to $5 \mathrm{ml}$ for gas chromatography analysis.

\section{Determination of Saponin Composition [17]}

\section{Procedure}

The sample was pulverized and the saponin was extracted three times with redistilled methanol. The saponins were removed with $20 \mathrm{ml}$ of the solvent for 20 minute with ultrasonification. The combined extracts were concentrated to syrup under reduced pressure and then suspended in water. The suspension was extracted with petroleum ether, chloroform and 1-butanol saturated with water, successively to give the respective extract after removal of the solvent. The combined extract was filtered and concentrated to $1 \mathrm{ml}$ in the vial for gas chromatography analysis and $1 \mu \mathrm{l}$ was injected into the injection port of GC.

\section{Determination of Glycoside Composition [18]}

\section{Procedure}

One gram of the pulverized sample was weighed into a precleaned borosilicate beaker, and extracted by pouring $10 \mathrm{ml}$ of ethanol/water $(7: 3 \mathrm{v} / \mathrm{v})$ mixture on it, and allowing to stand for $2 \mathrm{hrs}$. The mixture was filtered with Whatman No. 1 filter paper. The extract was purified by washing with lead acetate. The purified extract was further purified by adding sodium hydrogen phosphate. The extract was concentrated to $1 \mathrm{ml}$, for gas chromatographic analysis.

\section{Determination of Fatty acid Composition [19]}

\section{Procedure}

Fifty milligrams of the extracted fat content of the sample was saponified (esterified) for five minutes at $95^{\circ} \mathrm{C}$ with $3.4 \mathrm{ml}$ of the $0.5 \mathrm{M} \mathrm{KOH}$ in dry methanol. The mixture was neutralized by using $0.7 \mathrm{M}$ HCL. Three millilitres $(3 \mathrm{ml})$ of the $14 \%$ boron triflouride in methanol was added. The mixture was heated for 5 minutes at the temperature of $90^{\circ} \mathrm{C}$ to achieve complete methylation process. The Fatty acid methyl esters were thrice extracted from the mixture with redistilled $n$-hexane. The content was concentrated to $1 \mathrm{ml}$ for gas chromatography analysis. 


\section{RESULTS AND DISCUSSION}

\section{Proximate Composition of Costus afer Stem.}

The results of the proximate composition of the stem of Costus afer are presented in Table 4.1. The total carbohydrate composition of Costus afer stem was the highest (54.98\%) while crude fat had the lowest value of $1.15 \%$. The moisture content had a moderate value of $22.15 \%$ while total ash $(4.60 \%)$, crude protein $(7.72 \%)$ and crude fibre $(9.40 \%)$ were low.
Table 4.1: Proximate Compositions of Costus afer stem

\begin{tabular}{ll}
\hline Parameter & Composition \\
\hline Moisture (\%) & 22.15 \\
Total Ash (\%) & 4.60 \\
Crude Protein (\%) & 7.72 \\
Crude Fat (\%) & 1.15 \\
Crude Fibre (\%) & 9.40 \\
Total Carbohydrate (\%) & 54.98 \\
Caloric value (kcal) & 261.15 \\
\hline
\end{tabular}

Fatty acid Composition

Table 4.2: Fatty acid composition of Costus afer stem

\begin{tabular}{lcc}
\hline Compounds & Costus afer & \\
\hline & Retention time (min) & Composition (\%) \\
Caprylic acid (C8:0) & 8.908 & 0.00 \\
Capric acid (C10:0) & 10.363 & 0.00 \\
Lauric acid (C12:0) & 12.100 & 0.00 \\
Myristic acid (C14.0) & 13.743 & 0.02 \\
Palmitic acid (C16:0) & 15.160 & 25.48 \\
Palmitoleic acid (C16:1) & 16.248 & 2.06 \\
Margaric acid (C17:0) & 17.230 & 0.00 \\
Stearic acid (C18:0) & 18.057 & 6.37 \\
Oleic acid (C18:1) & 18.844 & 7.11 \\
Linoleic acid (C18:2) & 19.523 & 25.90 \\
Linolenic acid (C18:3) & 21.824 & 32.27 \\
Arachidonic acid (C20:0) & 22.359 & 0.52 \\
Arachidonic acid (C20:4) & 23.234 & 0.00 \\
Behenic acid & 23.970 & 0.20 \\
Erucic acid & 24.793 & 0.00 \\
Lignoceric acid & 25.619 & 0.07 \\
\hline Total fatty acids & & $\mathbf{1 0 0 . 0 0}$ \\
\hline
\end{tabular}

The content of fatty acids present in the stem of Costus afer investigated is shown in Table 4.2. The plant showed high contents of palmitic acid (25.48\%), linoleic acid (25.89\%), and linolenic acid (32.26\%) and moderate levels of oleic acid (7.11\%) and stearic acid (6.36\%) while myristic acid, palmitoleic acid, arachidonic acid, behenic acid and lignoceric acid was low and caprylic acid, capric acid, lauric acid, margaric acid, arachidonic acid, erucic acid were absent.

\section{Phytochemical Profile}

The results of the phytochemical analysis of the stem of Costus afer are shown below. Table 4.3a shows the alkaloid composition of the stem of Costus afer. The total alkaloid composition was $70.59 \mathrm{mg} / 100$. The plant showed high composition of papaverine $(44.72 \%)$, methyl morphine (23.24\%), morphine $(17.92 \%)$ and narcotine $(14.11 \%)$ while biflorin, daphnoline, aromoline, homoaromoline, ambelline, 6-hydroxyphanidine, monocrotalline, 6hydroxypowelline and nitidine concentrations were negligible.

Table 4.3a: Alkaloid composition of Costus afer stem

\begin{tabular}{lcc}
\hline Compounds & \multicolumn{1}{c}{ Costus afer } \\
\hline & Retention time (min) & Composition(mg/100g) \\
Morphine & 12.412 & 12.65 \\
Methyl morphine & 13.794 & 16.41 \\
Papaverine & 15.111 & 31.56 \\
Biflorin & 15.722 & 0.01 \\
Narcotine & 16.368 & 9.96 \\
Daphnoline & 16.664 & 0.00 \\
Aromoline & 18.042 & 0.00 \\
Homoaromoline & 18.988 & 0.00 \\
Ambelline & 19.665 & 0.00 \\
6-Hydroxybuphanidine & 20.599 & 0.00 \\
Monocrotalline & 21.251 & 0.00 \\
6-Hydroxypowelline & 21.794 & 0.00 \\
Nitidine & 22.559 & 0.00 \\
\hline Total alkaloids & & $\mathbf{7 0 . 5 9}$ \\
\hline
\end{tabular}


The flavonoid composition of the stem of Costus afer is presented in Table 4.3b. The total flavonoids concentration was $28.29 \mathrm{mg} / 100 \mathrm{~g}$. Myricetin $(69.79 \%)$ had the highest value with moderate levels of quercetin $(14.88 \%)$ and kaempferol (9.78\%) while catechin, resveratrol, apigenin, daidzein, butein, naringenin, biochanin, luteolin, epicatechin, salvegin, epicatechin-3-gallate, gallocatechin, sinensetin, kaempferol-3-arabinoside, quercitrin, isorquercetin, orientin, isoorientin and rutin levels were negligible.

Table 4.3b: Flavonoid Composition of Costus afer stem

\begin{tabular}{lcc}
\hline Compounds & Costus afer & \\
\hline & Retention time (min) & Composition(mg/100g) \\
Catechin & 13.549 & 0.00 \\
Resveratrol & 14.904 & 0.00 \\
Apigenin & 16.036 & 0.92 \\
Daidzein & 16.246 & 0.06 \\
Butein & 16.458 & 0.00 \\
Naringenin & 16.671 & 0.00 \\
Biochanin & 17.357 & 0.00 \\
Luteolin & 17.769 & 0.07 \\
Kaempferol & 18.050 & 2.77 \\
Epicatechin & 19.395 & 0.00 \\
Salvagenin & 20.467 & 0.00 \\
Epicatechin-3-gallate & 21.501 & 0.00 \\
Gallocatechin & 22.065 & 0.00 \\
Quercetin & 22.597 & 4.21 \\
Isorhamnetin & 23.471 & 0.00 \\
Myricetin & 23.965 & 19.75 \\
Sinensetin & 24.997 & 0.00 \\
Kaempferol-3-arabinoside & 25.360 & 0.00 \\
Naringenin & 26.041 & 0.00 \\
Quercitrin & 27.294 & 0.04 \\
Isoquercetin & 27.480 & 0.07 \\
Orientin & 27.910 & 0.00 \\
Rutin & 28.195 & 0.39 \\
Isoorientin & 28.529 & 0.02 \\
\hline Total flavonoids & & $\mathbf{2 8 . 2 9}$ \\
\hline
\end{tabular}

Table 4.3c: Saponin Composition of Costus afer stem

\begin{tabular}{lcc}
\hline Compounds & \multicolumn{1}{c}{ Costus afer } \\
\hline & Retention time (min)) & Composition(mg/100g) \\
Gitogenin & 17.545 & 0.08 \\
Solagenin & 18.588 & 0.01 \\
Diosgenin & 19.516 & 0.75 \\
Tigogenin & 20.115 & 0.28 \\
Neohecogenin & 20.979 & 0.00 \\
Hecogenin & 21.819 & 0.00 \\
Sapogenin & 22.600 & 1.12 \\
Euphol & 24.185 & 0.00 \\
Saponine & 25.480 & 0.63 \\
\hline Total saponins & & 2.87 \\
\hline
\end{tabular}

The concentrations of saponin compounds in the stem of Costus afer investigated are presented in Table 4.3c. The total composition of saponin was $2.87 \mathrm{mg} / 100 \mathrm{mg}$. The sapogenin content of the stem $(39.20 \%)$ was the highest with moderate levels of diosgenin (26.13\%), saponine $(22.12 \%)$ and tigonine $(9.76 \%)$ while gitogenin $(2.28 \%)$ was low and solagenin, neohecogenin, hecogenin and euphol were absent. 
Table 4.3d: Glycoside composition of Costus afer stem

\begin{tabular}{lcc}
\hline Compounds & \multicolumn{1}{c}{ Costus afer } \\
\hline & Retention time (min) & Composition(mg/100g) \\
Kampferol-3-0-Rhamnoside & 15.395 & 0.24 \\
Arbutin & 17.464 & 0.21 \\
Salicin & 18.758 & 1.06 \\
Amygdalin & 19.513 & 0.00 \\
Ouabain & 20.469 & 0.44 \\
Digitoxin & 21.436 & 1.03 \\
Vitexicarpin & 22.688 & 0.15 \\
Digoxin & 23.110 & 1.40 \\
Costugenin & 23.963 & 14.66 \\
\hline Total glycosides & & 22.35 \\
\hline
\end{tabular}

The concentrations of glycoside compounds in the stem of Costus afer investigated are presented in Table 4.3d. Costugenin $(65.60 \%)$ had the highest value with moderate levels of digitoxin (18.73\%), salicin (4.76\%), digoxin $(6.28 \%)$ and low levels of ouabain $(1.95 \%)$ and kaemferol3 -rhamnoside $(1.08 \%)$ while arbutin, amygdalin and vitexicarpin were absent.

\section{DISCUSSION}

Proximate composition of the stems of Costus afer in Table 4.1 showed that its moisture content was $22.15 \%$ and is high compared to $11.23 \%$ reported for the stems of Balanites aegyptiaca [20] but lower than those of Tridax procumbens (88.30\%) and Ocimum gratissimum (82.60\%).[21] [22] The moisture content of any food is used as a measure of stability and the susceptibility to microbial contamination. ${ }^{[23]}$ This implies that Costus afer may have a short shelf life due to its high moisture content.

The study indicated that the ash content of the stem was $4.60 \%$ and is lower than $13.67 \%$ reported for the stem of Ocimum gratissimum[22] which implies that the stems of Costus afer is a poor source of mineral element since the ash content of a plant material is an index of mineral contents in biota.

The protein content of the stem of Costus afer was $7.72 \%$ which is lower than $37.44 \%$ reported for Tridax procumbens[21] but higher than those of Ocimum gratissimum (1.65\%).[22] Proteins act as enzymes, hormones and antibodies. They are responsible for the formation of bones, teeth, hair and the outer layer of skin and they help maintain the structure of blood vessels and other tissues.[24] The result revealed that the stems of the plant are poor sources of protein.

The crude fat content of the plant was $1.15 \%$ and is lower than that of Aspilia africana which was 3.86\%[25].The finding showed that the plant is a poor source of plant lipid thus advantageous healthwise in avoiding overweight.[26] The crude fibre content was $9.40 \%$ and is high compared to that of Eugenia uniflora (0.67\%).[27] Adequate intake of dietary fibre can lower the serum cholesterol level, and thus risk of coronary heart disease, hypertension, diabetes, breast cancer and constipation. [28][29] Dietary fibers alter the colonic environment in such a way as to protect against colorectal diseases. They provide protection by increasing fecal bulk, which dilutes the increased colonic bile acid concentrations that occur with a high fat diet. [30]

The study revealed the carbohydrate content of the plant to be $54.98 \%$ which is higher than that of Tridax procumbens $(41.03 \%)^{[21]}$ but is lower than $58.35 \%$ reported for the stems of Balanites aegyptiaca.[20] Carbohydrates are the human body's key source of energy, providing 4 calories of energy per gram. Carbohydrates provide the body with a source of fuel and energy that is required to carry out daily activities and exercise.

The caloric value of the plant $(261.15 \mathrm{kcal} / 100 \mathrm{~g})$ is lower than those of Ocimum gratissimum $(278.42 \mathrm{kcal})$ and Tridax procumbens $(321.54 \mathrm{kcal}) .{ }^{[21][22]}$

The result of the fatty acid composition of the plant (Table 4.2) indicates the presence of linolenic acid which had the highest value of $32.27 \%$. Linolenic acid has been beneficial in lowering body fat. $\alpha$-linolenic acid is a polyunsaturated (Omega-3) fatty acid. Preliminary research has found evidence that $\alpha$-linolenic acid is related to a lower risk of cardiovascular disease. Dietary $\alpha$-linolenic acid has been assessed for its role in cardiovascular health. ${ }^{[31]}$ Linoleic acid was also found to be present at the concentration of $25.90 \%$. It is a polyunsaturated fatty acid used in the biosynthesis of arachidonic acid and thus some prostaglandins. [32] Linoleic acid is an essential fatty acid that must be consumed for proper health. These polyunsaturated fatty acids are able to decrease the plasmatic levels of VLDL, LDL cholesterol and increases in serum High density lipoprotein cholesterol expression of LDL receptors in liver. These LDL receptors increases uptake and subsequent removal of LDL, VLDL and thus restore cholesterol homeostasis.

Palmitic acid was found to be $25.48 \%$. Palmitic acids are needed for energy, hormone production, organ padding and cellular membranes. It is also needed for important signaling and stabilization processes in the body.

Oleic acid composition was $7.11 \%$. It is a monounsaturated fat in human diet. Monounsaturated fat consumption has been associated with decreased low density lipoprotein (LDL) cholesterol and possible increased high density lipoprotein (HDL) cholesterol. Oleic acid may be responsible for the hypotensive (blood pressure reducing) effects of olive oil. [33]

The result of the phytochemical analysis indicated the presence of alkaloids, saponins, flavonoids, glycosides. Alkaloids are known to have anti-microbial, antifungal and anti-inflammatory effect ${ }^{[3]}$ and it also acts as an antihypertensive agent.[34] Table $4.3 \mathrm{a}$ shows the result of the quantification of alkaloid compounds present in the stems of Costus afer. The plant contained papaverine, an alkaloid which had the highest value of $31.56 \mathrm{mg} / 100 \mathrm{~g}$ than other alkaloid compounds. It is used to treat spasms of the gastrointestinal tract, bile ducts and ureter and for use as cerebral and coronary vasodilators in subarachnoid hemorrhage [35] and coronary artery bypass surgery. ${ }^{[36]}$ It relaxes veins and arteries, which makes them wider and allows blood to pass through them more easily, thereby increasing the amount of oxygen rich blood in the brain, 
heart and muscles. It is also used as an erectile dysfunction drug, alone or sometimes in combination. [37][38]

Morphine, an alkaloid with the value $12.65 \mathrm{mg}$ was present in the plant and they are narcotic analgesics used to relieve severe pain. It is primarily used to treat both acute and chronic pain. Also used for pain due to myocardial infarction and for labour pains. ${ }^{[39]}$ Also methyl morphine an alkaloid referred to as codeine with the value $16.41 \mathrm{mg} / 100 \mathrm{mg}$ was present in the plant. It is used as a cough suppressant, analgesic and hypnotic. It is also used to treat diarrhea.[40] Narcotine $(9.96 \mathrm{mg} / 100 \mathrm{~g})$ was also present. It has an antitussive effect. It is currently under investigation for use in the treatment of several cancers and hypoxic Ischemia in stroke patients.

Table 4.3b shows the result of flavonoid compounds present in the stems. Collectively, flavonoids are of particular importance in the human diet as there is evidence that they act as antioxidants, antiviral and antiinflammatory agents ${ }^{[41]}$ and are associated with reduced risk of cancer and cardiovascular diseases. [42][43] Myricetin, a flavonoid was found to have the highest concentration of $19.74 \mathrm{mg} / 100 \mathrm{~g}$ in the plant. Myricetin in high concentrations can modify LDL cholesterol such that uptake by white blood cells is increased and also lowers rates of prostate cancer.[44] Invitro studies show that flavonoids have anti- diarrheal activities.[45] Flavonoids such as Quercetin $(4.21 \mathrm{mg} / 100 \mathrm{~g})$ was also present and it has efficacy against the Group 1 carcinogen helicobacter pylori ${ }^{[46]}$ and kaempferol $(2.77 \mathrm{mg} / \mathrm{kg})$ was also detected. Kaempferol, quercetin and myricetin reduced the risk of pancreatic cancer by 23 percent in an 8 year study.[47]

The presence of flavonoids suggests that the plant might have anti-oxidant, anti-allergic, anti-inflammatory, antimicrobial and anti-cancer activities.

Table 4.3c shows saponin compounds present in the stem of Costus afer. Saponins are reported to have broad range of pharmacological properties. ${ }^{[41]}$ The presence of saponin

\section{REFERENCES}

1. Okwu, D.E. (2005). Phytochemicals, Vitamins and Mineral Content of Two Nigeria Medicinal Plants. International Journal of Molecular and Advance Sciences, 1(4): 375-381.

2. Uruquiaga, I. and Leighton F. (2000). Plant Polyphenol Antioxidants and Oxidative Stress. Biological Research, 33: 159-165.

3. Okwu, D.E. and Okwu, M.E. (2004). Chemical Composition of Spondias mombim Linn Plants Parts. Journal of Sustainable Agriculture and Environmental, 6: 140-147.

4. Akpan, M.M., Odeomena, C.S., Nwachukwu, C.N. and Danladi, B. (2012). Antimicrobial Assessment of Ethanolic Extract of Costus afer Leaves. Asian Journal of Plant Science and Research, 2(3): 335-341.

5. Evans, W.C. (2005). Biological and Geographical Sources of Drug. In Evans, W.C. (Ed) Trease and Evans Pharmacognosy, $15^{\text {th }}$ Edn. India: Elsevier, pp. 13-14.

6. Mccance, R.A. and Widdowson, E.M. (1940). The Composition of Foods. Medical Research Council Special Report. London: His Majesty's Stationery Office, pp. 235.

7. Melchias, G. (2001). Biodiversity and Conservation. Enfield. In: Emmanuel K. Boon and Luc Hens, (Eds.) Indigenous Knowledge Systems and Sustainable Development; Relevance for Africa Kamla-Raj Enterprises 2007 Tribes and Trials. Science Publishers Incorporation, 1: 121-139.

8. Edeoga, H.O. and Okoli, B.E. (2000). Chromosome Numbers of Costus lucanusianus (Costaceae) in Nigeria. Folia Geobotanica, 35: 315-318.

9. Iwu, M.M. (1983). Traditional Igbo Medicine. University of Nigeria, Nsukka: Institute of African Studies Publication, pp. 112-144.
$(2.86 \mathrm{mg} / 100 \mathrm{~g})$ in Costus afer stems suggests that the plant may act as anti-inflammatory, anti-fungal, expectorant, vasoprotective, hypocholesterolemic, anti-parasitic, hypoglycaemic and many others.[48][49] Nwauche et al., 2014 reported that the stem of Costus afer has antihyperglycemic potentials. Sapogenin had the highest value of $1.12 \mathrm{mg} / 100 \mathrm{~g}$. Diosgenin, a saponin had a concentration of $0.75 \mathrm{mg} / 100 \mathrm{~g}$. Diosgenin is the precursor for the semisynthesis of progesterone [50] which in turn was used in early combined oral contraceptive pills.[51] It has an estrogenic activity and can reduce the level of serum cholesterol.[52][53] Saponins are used as adjuvants in vaccines, they form complexes with cholesterol to form pores in cell membrane bilayers. ${ }^{[54]}$ They are antiinflammatory compounds that lower blood cholesterol and prevent heart disease as well as some cancers.[55]

Table $4.3 \mathrm{~d}$ shows the compositions of glycoside compound present in the plant. Costugenin had the highest value of $14.66 \mathrm{mg} / 100 \mathrm{~g}$. Cardiac glycosides are used in the treatment of heart diseases like congestive heart failure and arrhythmia. Digoxin and Digitoxin were present in the plant with values $1.40 \mathrm{mg} / 100 \mathrm{~g}$ and $1.03 \mathrm{mg} / 100 \mathrm{~g}$. They are widely used in the treatment of various heart conditions, namely atrial fibrillation and sometimes heart failure that cannot be controlled by other medication. Digoxin and Digitoxin increases the strength of heart contraction. Salicin content was $1.06 \mathrm{mg} / 100 \mathrm{~g}$. Salicin has been shown to have anti-inflammatory, anti-pyretic effect. Salicin aids in lowering production of two enzymes, prostaglandins and thromboxanes, which reduces inflammation and the potential of platelets to stick to one another, by acting as a natural oil cleanser to wipe up the sticky and greasy layer on platelet surfaces, lessening risk of blood clots, heart attacks and strokes.[56] The presence of cardiac glycosides in Costus afer stems shows that the plant is good for the treatment of diseases associated with heart. The alkaloid composition $(70.58 \mathrm{mg} / 100 \mathrm{~g})$ of the plant was higher than other phytochemicals present.

10. Aweke, G. (2007). Costus afer (Ker Gawl). In: Schmelzer, G.H and Gurib-Fakim, A. (Eds). Medicinal Plants. Plant Resources of Tropical Africa, 11:1

11. Nyananyo, B.L. (2006). Plants from the Niger Delta International Journal of Pure and Applied Sciences, 3(4): 2125.

12. Nwauche, K. T., Monago, C.C. and Anacletus, F.C. (2014) Antihyperglycemic activity of the aqueous extract of Costus afer stem alone and in combination with metformin. European journal of biotechnology and bioscience 1 (5): 1925.

13. Anaga, A.O., Njoku, C.J., Ekejiuba, E.S., Esiaka, M.N. and Asuzu I.U. (2004). Investigation of the Methanolic Leaf Extract of Costus afer Ker Gawl for Pharmacological Activities In Vitro and In Vivo. Phytomedicine, 11(2-3): 242-248.

14. Association of Official Analytical Chemists (AOAC) (2006). Official Methods of Analysis of AOAC (W.Horwitiz, Ed.) $18^{\text {th }}$ Edn. Washington, D.C., 1: 600-792.

15. Ngounou, F.N., Manfouo, R.N., Tapondjou, L.A., Lontsi, D., Kuete, Penlap, V., Etoa, F.X., Dubois, M.A.L. and Sondengam, B.L. (2005). Antimicrobial Diterpeniod Alkaloids from Erythrophleum Suavelens Brenan. Bulletin of the Chemical Society of Ethiopia, 19(2), 221-226.

16. Harborne, J.B. (1989). General Procedures and Measurement of Total Phenolics. In: Methods in Plant Biochemistry. London: Academic Press, 1:1-28.

17. Mingquan, G, Lei, Z. and Zhiqiang, L. (2009). Analysis of Saponins from Leaves of Aralia Elata by Liquid Chromatography and Multistage Tandem Mass Spectrometry. London: Arnold, pp. 754. 
18. Oluwaniyi, O.O. and Ibiyemi, S.A. (2007). A Study of the Extractability of Thevetia Glycosides with Alcohol Mixture. Journal of Food Technology, 5(2): 147-151.

19. Palmquist, D.L. and Jenkins, T.C. (2003). Challenges with Fats and Fatty Acid Methods. Journal of Animal Science, 81: 32503254.

20. Idris, S., Ndamitso, M.M., Yisa, J., Dauda, B.E.N. and Jacob, J.O. (2010). The Proximate and Mineral Composition of the Leaves and Stems of Balanites aegyptiaca. International Journal of Applied Biological Research, 2(1): 76-87.

21. Ikewuchi, J. (2009). Chemical Profile of Tridax procumbens linn. Pakistan Journal of Nutrition, 8(5): 548-550.

22. Idris, S., Iyaka, Y.A., Ndamitso, M.M. and Paiko, Y.B. (2011). Nutritional Composition of the Leaves and Stems of Ocimum gratissimum. Journal of Emerging Trends in Engineering and Applied Sciences, 2(5): 801-805.

23. Uraih, N. and Izuagbe, Y. (1990). Public Health, Food and Industrial Microbiology. Nigeria: Uniben Press, pp. 250.

24. Javid, H., Abdul, L. K., Najeeb, U. R., Zainullah, F. K., Sejed, T and Zabta, K. S. (2009). Proximate and Nutrient Investigations of Selected Medicinal Plants Species of Pakistan. Pakistan Journal of Nutrition, 8: 620-624.

25. Essiett, U.A. and Akpan, E.M. (2013). Proximate Composition and Phytochemical Constituents of Aspilia africana and Tithonia diversifolia Stems. Bulletin of Environment, Pharmacology and Life Sciences, 2(4): 33-37.

26. Lintas, C. (1992). Nutritional Aspects of Fruits and Vegetables Consumption. Options Mediterraeennes, 19: 79-87.

27. Okoh, E., Uchechukwu, R., Husseini, S.J. and Asuquo, T.S. (2011). Proximate and Phytochemical Analysis of Leaf, Stem and Root of Eugenia uniflora. Journal of Natural Product and Plant Resources, 1(4): 1-4.

28. Ishida, H., Suzuno, H., Sugiyama, N., Innami, S., Todokoro, T. and Maekawa, A. (2000). Nutritional Evaluation of Chemical Component of Leaves Stalks and Stems of Sweet Potatoes (Ipomoea Batatas Poir). Food Chemistry, 68: 359-367.

29. Ramula, P. and Rao, P.U. (2003). Dietary Fibre Contents of Fruits and Leafy Vegetables. Nutrition News, 24(3): 1-6.

30. Dillard, C.J. and German, J.B. (2000). Phytochemicals: Nutraceuticals and Human Health. Journal of Science of Food \& Agriculture, 80(12): 1744-1756.

31. Penny, M.K., Williams, S.H. and Lawrence, J.A. (2002). Fish Consumption, Fish Oil, Omega-3 Fatty Acids, and Cardiovascular Disease. Circulation, 106(21): 2747-2757.

32. Cunnane, S. and Anderson, M. (1997). Pure Linoleate Deficiency in the Rat: Influence on growth, accumulation of n6 polyunsaturates, and $\left(1-{ }^{-14} \mathrm{C}\right)$ linoleate oxidation. Journal of Lipid Research, 38 (4): 805-812.

33. Teres, S., Barcelo-Coblijn, G., Benet, M., Alvarez, R., Bressani, R., Halver, J.E. and Escriba, P.V. (2008). Oleic Acid Content is Responsible for the Reduction in Blood Pressure Induced by Olive Oil. National Academy of Sciences, 105 (37): 1381113816.

34. Sofowora, A. (1993). Medicinal Plants and Traditional Medicine in Africa. Ibadan: Spectrum Books Ltd, pp. 289.

35. Liu, J.K. and Couldwell, W.T. (2005). Intra-Arterial Papaverine Infusions for the Treatment of Cerebral Vasospasm Induced by Aneurysmal Subarachnoid Hemorrhage. Neurocrit Care, 2(2): 124-132.

36. Takeuchi, K., Sakamoto, S., Nagayoshi, Y., Nishizawa, H. and Matsubara, J. (2004). Reactivity of the Human Internal Thoracic Artery to Vasodilators in Coronary Artery Bypass Grafting. European Journal of Cardiothoracic Surgery, 26(5): 956-959.

37. Desvaux, P. (2005). An Overview of the Management of Erectile Disorders. Presse Medicale, 13:5-7.
38. Bella, A.J. and Brock, G.B. (2004). Intracavernous Pharmacotherapy for Erectile Dysfunction. Endocrine, 23(23): 149-155.

39. Meine, T.J., Roe, M.T. and Chen, A.Y. (2005). Association of Intravenous Morphine used and Outcomes in Acute Coronary Syndromes: Results from the Crusade Quality Improvement Initiative. American Heart Journal, 149(6): 1043-1049.

40. Stefano, G. and Haleh, V. (2010). Diarrhoea: Diagnostic and Therapeutic Advances. New York: Humana Press, pp. 452.

41. Soetan, K.O. (2008). Pharmacological and other Beneficial Effects of Anti-Nutritional Factors in Plants. A Review: African Journal of Biotechnology, 7: 4713-4721.

42. Middleton, R. J., Kandaswani, C. and Theoharides, T.C. (2000). The Effects of Plant Flavonoids on Mammalian Cells: Implications for Inflammation, Heart Disease and Cancer. Pharmacological Reviews, 52: 673-751.

43. Grubesic, R.J., Vukovic, J., Kremer, D. and Vladimir-Knezevic, S. (2007). Flavonoid Content Assay: Prevalidation and Application on Plantago Species. Acta Chimica Slovenica, 54: 397-406.

44. Knekt, P., Kumpulainen, J. and Jarvinen, R. (2002). Flavonoid Intake and Risk of Chronic Diseases. American Journal of Clinical Nutrition, 76(3): 560-568.

45. Schuier, M., Sies, H, Lllek, B and Fisher, H. (2005). CocoaRelated Flavonoids Inhibit CFTR-Mediated Chloride Transport across T84 Human Colon Epithelia. Journal of Nutrition, 135(10): 2320-2326.

46. Gonzalez-Segovia, R., Quintanar, J.L., Salinar, E., CeballosSalazar, R., Aviles-Jimenez, F. and Torres-Lopez, J. (2008). Effect of the Flavonoid Quercetin on Inflammation and Lipid Peroxidation Induced by Helicobacter Pylori in Gastric Mucosa of Guinea Pig. Journal of Gastroenterology, 43(6): 441-447.

47. Nothings, U., Murphy, S.P., Wilkens, L.R., Henderson, B.E. and Kolonel, L.N. (2007). Flavonols and Pancreatic Cancer Risk. The Multiethnic Cohort Study. American Journal of Epidemiology, 166(8): 924-931.

48. Sparg, S.G., Light, M.E. and Staden, J. (2004). Biological Activities and Distribution of Plant Saponins. Journal of Ethnopharmacology, 94: 219-243.

49. Sahu, N.P., Baner Jee, S., Mondal, N.B. and Mandal, D. (2008). Steroidal Saponins. In: Progress in the Chemistry of Organic Natural Products, Vol 89. Vienna: Spinger, pp. 45-141.

50. Marker, R.E. and Krueger, J. (1940). Sterols. CXII. Sapogenins. XLI. The Preparation of Trillin and its Conversion to Progesterone. Journal of the American Chemical Society, 62(12): 3349-3350.

51. Djerassi, C. (1992). Steroids Research at Syntax. The Pill and Cortisone: Steroids, 57(12): 631-641.

52. Liu, J., Sempos, C., Donahue, R., Dorn, J., Trevisan, M. and Grundy, S.M. (2005). Joint Distribution of Non-HDL and LDLCholesterol and Coronary Heart Disease Risk Prediction among Individuals with and without Diabetes. Diabetes Care, 28(8): 1916-1921.

53. Cayen, M.N. and Dvornik, D. (1979). Effects of Diosgenin on Lipid Metabolism in Rats. Journal of Lipid Research, 20(2): 162-174.

54. Francis, G., Zohar, K., Harinder, P.S.M. and Klaus, B. (2002). The Biological Action of Saponins in Animal Systems: A Review. British Journal of Nutrition. 88(6): 587-605.

55. Kervinen, J., Tobin, G.J., Costa, J. Waugh, D.S., Wlodawer, A. and Zdanov, A. (1999). Crystal Structure of Plant Aspartic Proteinase Prophytepsin: Inactivation and Vacuolar Targeting. Embo Journal, 18: 3947-3955.

56. Richtmyer, N.K. and Yeakel, E.H. (1934). The Structure of Populin. Journal of the American Chemical Society, 56 (11): 2495-2497 